\title{
PELATIHAN PENGEMBANGAN PRODUKSI GULA BRIKET AREN DENGAN PENGEMASAN MENARIK YANG MEMILIKI NILAI JUAL TINGGI BAGI MASYARAKAT DESA BUKIT TINGGI
}

\author{
Ahmad Sulhan \\ Institut Agama Islam Negeri Mataram \\ E-mail: ahmadsulhan91@gmail.com
}

\begin{abstract}
Abstrak: Dalam mengembangkan produksi gula briket aren dengan kemasan menarik yang memiliki nilai jual tinggi sebagai trend konsumen yang cenderung mudah tertarik dengan kemasan menarik sekarang ini, karena itu hasil pelatihan ini mengedepankan konsep fungsi kemasan bukan hanya menjadi pelindung untuk sebuah produk, melainkan sebuah kemasan juga harus mampu memberi citra bagi produk, dengan demikian produk akan dengan mudah dapet diingat melalui kemasannya. Rasa dari produk yang enak tidaklah cukup untuk menarik pembeli, sehingga penambahan unsur visual agar produk menjadi lebih menarik bagi pembeli sangatlah penting. Pengabdian ini bertujuan untuk:(1) Membangun mindset pengusaha gula briket aren yang kreatif dan percaya diri, (2) Mendesain pengemasan menarik yang memiliki nilai jual tinggi. Pengabdian ini menggunakan strategi-strategi yang dilakukan secara partisipatif untuk mencapai kondisi harapan tersebut, antara lain Livelihood Analysis dan Trends and Changes. Hasil pengabdian ini dapat mengembangkan kemasan gula briket aren yang menarik memiliki nilai jual tinggi berdasarkan Brand Image yang ingin ditampilkan pada kemasan tradisional dan modern yaitu simplicity. Ilustrasi yang ditambahkan adalah gambar pohon aren sebagai penegas bahwa produk-produk yang dihasilkan terbuat dari pohon aren. Serta ditambahkan pula identitas produksi: KUBE Bukit Aren, Desa Bukit Tinggi Kecamatan Gunungsari, Kontak Person, dan gambar Gula Briket Aren. Dan juga terdapat motif kebon aren memberikan kesan alami yang melambangkan bahwa produk-produk Gula Briket Aren tersebut dibuat secara alami. Aplikasi Desain Logo Gula Briket Aren mempunyai kesan simplicity dan tradisional untuk menampilkan produk yang dijual yaitu gula aren yang diolah secara tradisional dan alami yaitu dengan pemakaian logogram dan logotype yang menunjang logo. Proses pembuatan logo Gula Briket Aren dimulai dari proses thumbnail, tight tissue, dan final.
\end{abstract}

Kata Kunci: Pengembangan, produksi gula briket aren, kemasan menarik, nilai jual tinggi.

\section{PENDAHULUAN}

Pengembangan produksi gula briket aren dapat dilakukan dengan, pertama membangun mindsetpengusaha gula briket aren yang kreatif dan percaya diri, serta kedua, mendisain pengemasan menarik yang memiliki nilai jual tinggi.

Pertama, perjun ke dunia bisnis tentu bukanlah hal yang mudah, selain karena butuh perjuangan yang keras agar bisa menjadi sukses sebagai pengusaha, pendapatan yang tidak tetap pun juga membayang-bayangi seseorang yang ingin terjun ke dunia usaha, tak terkecuali dunia usaha gula briket aren. Tapi jika seseorang memang punya jiwa wirausaha, tentu halangan seperti itu tidak akan 
menciutkan nyali bukan. Nah mindset seperti inilah yang sebenarnya bisa menjadi modal awal seseorang ketika akan terjun ke dunia bisnis (tak terkecuali bisnis produksi gula briket aren) yang harus dilatih melalui Desa Binaan ini. Berikut ulasan mengenai mindset pengusaha sukses yang harus dibangun dan dimiliki oleh pengusaha gula briket aren:

\section{a. Its Not Just About Money}

Ketika kita ingin terjun ke dunia bisnis, kebanyakanya orang pasti akan berpikir tentang berapa jumlah modal yang harus disiapkan untuk membuat bisnis tersebut berjalan. Dan sebagian besar dari kita akan kebingungan, bagaimana caranya bisa mendapatkan modal untuk memilai usaha tersebut. Kalau selama ini Anda hanya berpikir tentang modal materiil, saatnya buang jauhjauh pikiran itu.

Modal utama seorang pengusaha bukanlah uang, melainkan kreativitas. Ketika kita memiliki kreativitas, akan lebih mudah untuk mendapatkan modal.

\section{b. Membuang Jauh-Jauh Rasa Tidak Percaya Diri}

Rasa tidak percaya diri adalah momok yang sering membuat seorang calon pengusaha menjadi galau saat akan membangun sebuah bisnis. Para pengusaha gula briket aren harus dilatih untuk buang jauh-jauh perasaan tidak percaya diri bila serius ingin bergelut di dunia bisnis. Karena kalau tidak, bisnis gula briket aren mereka tidak akan berkembang dan bahkan bisa saja menjadi bangkrut. Tentu setiap pengusaha gula briket aren tidak mengharapkan hal seperti itu terjadi.

\section{c. Sukses di Dunia Bisnis Tidak Ditentukan oleh Bakat}

Banyak yang berpendapat bahwa seseorang yang sukses di dunia bisnis karena ia mempunyai bakat yang luar biasa dalam berbisnis. Dan jika pengusaha pemula gula briket aren dihinggapi rasa tidak berbakat, maka lambat ataupun cepat merekapun pun akan mengurungkan niat untuk terjun lebih dalam ke dunia bisnis, mindset seperti ini adalah sebuah kekeliruan besar dan sering jadi penghalang seseorang untuk maju.

Seseorang yang sukses di dunia bisnis adalah pribadi yang memiliki keyakinan tinggi dan juga keuletan, bukan hanya karena bakat. Jadi jangan pernah merasa minder karena kurang berbakat, sebenarnya bakat itu bisa 
diganti dengan keuletan yang harus dilatihkan kepada para pengusaha gula briket aren untuk meraih kesuksesan sesuai dengan harapan.

\section{d. Tenang Saat Mengalami Cobaan dalam Berbisnis}

Setiap orang pasti akan selalu berhadapan dengan masalah dalam berbisnis, baik pada saat kita merintis ataupun pada saat sudah merasakan kesuksesan. Jadi, jika para pengusaha gula briket aren ingin menjadi seorang pengusaha yang sukses maka harus memiliki mental pantang menyerah dan cerdas dalam mencari solusi. Karena itu, para pengusaha gula briket aren harus terus melatih jiwa pantang menyerah dan selalu belajar mencari solusi terbaik dalam setiap permasalahan.

Intinya adalah, ketika seseorang berniat menjadi pengusaha gula briket aren maka harus benar-benar terjun sepenuhnya ke dunia usaha tersebut. Jangan setengah-setengah karena hasil yang akan didapatkan nantinya tidak akan maksimal. Apapun usaha para pengusaha gula briket aren, lakukanlah bisnis tersebut dengan serius.

Kedua. Berdasarkan wujudnya produk yang diangkat pada pelatihan ini, yaitu gula aren termasuk dalam klasifikasi barang, sebab produk ini dapat dilihat, dipegang, disimpan, dan dipindahkan. Berdasarkan daya tahannya, produk gula aren ini termasuk dalam jenis yang tahan lama, namun harus didukung dengan kemasan yang pas sehingga memiliki nilai jual tinggi. Dilihat dari tujuan konsumen dan kegunaan produk yang digunakan maka gula aren ini menjadi bahan baku untuk masakan, pemanis, dan lain-lain.

Lebih lanjut materi pelatihan desain kemasan menarik ini sebagai hasil refleksi dari kemasan yang ada sebelumnya yang dilakukan oleh pengusahapengusaha gula aren di Desa Bukit Tinggi yang ternyata kemasannya kurang menarik. Jika dilihat dari sisi visibility, kemasan terdapat tanda pengenal produk dengan label yang hanya dibuat seadanya dan tidak menarik. Baik pada ukuran $250 \mathrm{gr}$ ataupun $400 \mathrm{gr}$ produk hanya dikemas dengan menggunakan plastik mika tipis transparan dan dijepret bagian sampingnya. Ukuran plastik pas dengan produk yang dikemas.

Dari sisi information, tidak ada informasi apa pun pada kemasan. Tidak terdapat logo. Dari sisi emotional appeal, produk dengan menggunakan kemasan plastik ini cukup memberikan kesan higienis. Namun plastik yang tipis memberikan 
kesan bahwa produk tidak akan terlindungi dengan baik dan mudah hancur. Dari sisi workability, kemasan ini kurang tepat. Karena untuk ukuran kemasan produk ukuran besar sangatlah tidak aman. Karena banyak sekali produk yang terkikis karena plastik terlalu tipis dan sangat pas dengan ukuran yang sangat pas.

Dengan kemasan yang demikian ini, maka para konsumen akan sulit mengenali produk gula briket aren Desa Bukit Tinggi, karena sama sekali tidak terdapat logo dan perusahaan mana yang memproduksinya. Untuk segmen pasar yang lebih tinggi, kemasan sejenis ini sangat kurang tepat bila digunakan. Karena kemasan dengan plastik tipis tidak dapat melindungi produk, sehingga produk dapat dengan mudah hancur. Selain itu, desain yang kurang menarik beserta informasi yang tidak dicantumkan akan membuat orang untuk tidak tertarik mengkonsumsinya.

Karena itu, perancangan Desain Kemasan Gula Briket Aren Tradisional Produksi KUBE Bukit Aren Desa Bukit Tinggi harus memiliki tujuan, yaitu membuat kemasan yang menarik bagi gula briket aren, sehingga mampu membawa produk ke target market yang lebih luas dan meningkatkan brand awareness Gula Briket Aren. Konsep Kreatif Pada produk Gula Briket Aren ini terdapat tiga macam produk, yaitu gula aren padat, gula aren bubuk, dan gula aren cair, namun pada pelatihan ini hanya difokuskan pada gula aren padat. Masing-masing produk terdapat dua ukuran yang berbeda. Untuk gula aren padat dan cair akan dibuat label. Penggunaan warna hanya satu warna saja, yaitu warna coklat yang memberikan kesan tradisional dan juga merupakan warna dari gula aren itu sendiri serta untuk menekan biaya produksi.

\section{PEMBAHASAN}

Berdasarkan konsep tentang desain pengemasan menarik memiliki nilai jual tinggi, maka konsep kemasan yang dikembangkan, menghasilkan perancangan Desain Kemasan Gula Briket Aren Tradisional Produksi KUBE Bukit Aren Desa Bukit Tinggi memiliki tujuan, yaitu mampu membawa produk ke target market yang lebih luas dan meningkatkan brand awareness Gula Briket Aren. Konsep Kreatif Pada produk Gula Briket Aren ini terdapat tiga macam produk, yaitu gula aren padat, gula aren bubuk, dan gula aren cair, namun pada pelatihan ini hanya difokuskan pada gula aren padat. Masing-masing produk terdapat dua ukuran yang berbeda. Untuk 
gula aren padat dan cair akan dibuat label. Penggunaan warna hanya satu warna saja, yaitu warna coklat yang memberikan kesan tradisional dan juga merupakan warna dari gula aren itu sendiri serta untuk menekan biaya produksi.

Sebagai produk bahan makanan, maka yang penting adalah perlu diperhatikan kehigienisannya. Maka untuk menjaga produk tersebut bahan kemasan paling utama untuk gula bubuk padat adalah plastic warp. Plastic warp dapat melindungi makanan agar tahan lebih lama dan terlindungi. Untuk kemasan utama gula aren bubuk menggunakan flexible paper.

Namun, plastic wrap dan flexible paper tidak dapat berdiri sendiri sebagai bahan pengemas. Maka dari itu untuk gula aren padat digunakan kertas samson untuk melapisi bagian luar plastic wrap, yang mana bukan hanya sebagai pelindung tambahan namun juga berfungsi sebagai daya tarik serta menampilkan label informasi tentang produk yang ditempel pada kertas samson tersebut. Produk ini merupakan produk yang tidak mahal, maka bahan yang digunakan pun harus menyesuaikan.

Sehingga tidak dapat mementingkan visualnya saja agar terlihat menarik, namun juga harus diperhatikan bahwa harga kemasan tidak lebih tinggi dari harga produknya. Dalam hal ini harus dipikirkan kembali bagimana membuat desain yang menarik, namun harus tetap ekonomis sesuai dengan produk.

Dari hasil pelatihan yang telah dilakukan, telah didapatkan konsep utama dari desain adalah tradisional. Tradisional diperoleh dari bagaimana proses pengolahan dari air nira sampai menjadi gula aren. Tujuan utama dari perancangan desain kemasan gula aren tradisional ini tidak hanya untuk memperluas target marketnya ke tingkat yang lebih tinggi dalam hal ini target market yang lebih tinggi merupakan supermarket, tetapi juga mengenalkan brand menjadi lebih dikenali (brand awareness).

Dalam perancangan ini, akan dibuat sebuah kemasan yang sesuai dengan jenis produknya, sehingga produk yang sebelumnya kurang dikenali dapat hadir dengan tampilan yang menarik pembeli. Kemasan akan dirancang dengan mengutamakan sisi kepraktisan, ekonomis, higienis, serta tidak akan memberatkan produsen dari segi produksi serta konsumen dari segi harga.

Konsep secara keseluruhan dari desain kemasan adalah ingin menampilkan sisi tradisional yang disatukan dengan sisi modern, dengan menggunakan jenis 
desain yang sesuai dengan selera saat ini. Tetap diangkat desain dari sisi tradisonal karena tidak ingin meninggalkan sisi tradisional dari produk sendiri.

Dengan demikian produk gula aren dari para pengusaha gula aren desa Bukit Tinggi akan memiliki wajah baru, dan siap untuk maju ke market yang lebih tinggi. Berikut ini akan dijelaskan dan dilatih lebih lanjut mengenai brand positioning, brand identity, serta brand image dari produk gula aren tradisional KUBE Bukit Aren di Desa Bukit Tinggi.

\section{Brand Positioning}

Pada perancangan ini, positioning yang diharapkan adalah produk gula aren ini merupakan produk yang berkualitas, dan cocok dijadikan sebagai pemanis makanan dan minuman. Jadi persepsi yang ingin ditampilkan bagi konsumen adalah gula aren merupakan pemanis alami dan aman untuk dikonsumsi setiap orang bahkan untuk penderita diabetes. Produk ini dapat digunakan untuk campuran jamu, campuran bahan masakan, campuran makanan, dan juga campuran untuk minuman. Produk Gula briket aren ini diolah secara tradisional dan alami tanpa campuran bahan kimia, serta layak bila dikonsumsi.

\section{Brand Identity}

Identitas produk yang digunakan adalah Gula Briket Aren Desa Bukit Tinggi. Karena, seluruh produk merupakan hasil produksi dari para pengusaha gula briket aren dari desa Bukit Tinggi sendiri. Kata "Gula Briket Aren" dimaksudkan untuk memperjelas konsumen bahwa produk yang diproduksi dan dijual kepada masyarakat merupakan gula aren. Penggunaan nama Gula Briket Aren akan diaplikasikan pada setiap bagian dari desain kemasan hingga perangkat promosinya.

\section{Brand Image}

Brand Image yang ingin ditampilkan pada kemasan adalah kemasan tradisional dan modern yaitu simplicity. Ilustrasi yang ditambahkan adalah gambar pohon aren sebagai penegas bahwa produk-produk yang dihasilkan terbuat dari pohon aren. Serta ditambahkan pula identitas produksi: KUBE Bukit Aren, Desa Bukit Tinggi Kecamatan Gunungsari, Kontak Person, dan gambar Gula Briket Aren. Dan juga terdapat motif kebon aren memberikan kesan alami yang melambangkan bahwa produk-produk Gula Briket Aren tersebut dibuat secara 
alami. Aplikasi Desain Logo Gula Briket Aren mempunyai kesan simplicity dan tradisional untuk menampilkan produk yang dijual yaitu gula aren yang diolah secara tradisional dan alami yaitu dengan pemakaian logogram dan logotype yang menunjang logo. Proses pembuatan logo Gula Briket Aren dimulai dari proses thumbnail, tight tissue, dan final.

Logogram yang dipilih adalah penggabungan siluet dari pohon aren dan garis pada dasar pohon tersebut. Siluet pohon aren ini bermakna bahwa produkproduk yang dihasilkan terbuat dari pohon aren. Pohon aren dianalogikan sebagai merk itu sendiri yaitu "Gula Briket Aren".

Logotype dari Gula Briket Aren ini akan menggunakan typeface (font) yang berjenis script, serif, dan sans serif. Typeface script yang digunakan adalah Monotype Corsiva yang memberi kesan tradisional dan dinamis. Typeface serif yang digunakan adalah Castellaryang memberi kesan elegan. Typeface sans serif yang digunakan adalah Bebas Neueyang memberi kesan modern yaitu simplicity.

Warna pada logo terdapat warna coklat yang merupakan warna utama dan warna coklat tua. Warna coklat memberikan kesan tradisional dan warna coklat ini merupakan warna dari gula aren itu sendiri. Untuk menekan biaya produksi agar tidak terlalu tinggi, maka penggunaan warna yang akan diminimalisir. Dalam hal ini, kemasan utama akan dicetak dengan menggunakan sistem offset. Karena pada setiap kemasan hanya akan menggunakan satu warna saja, penggunaan warna gelap dan terang tetap ada. Namun, dalam teknik offset warna yang berbeda itu masih tetap dianggap satu warna, namun tinta akan keluar dengan tingkat kepekatan yang berbeda. Untuk persiapan cetak offset, data harus disimpan dalam format vektor dengan ukuran dari bidang objek sesuai dengan aslinya saat ada di media cetaknya. Untuk label kemasan cair dan padat juga menggunakan teknik cetak offset. Mulai dari film, plat, pisau potong, dan juga plong akan dikerjakan oleh percetakan offset. Sedangkan untuk kertas akan dibeli sendiri, atau jika sudah ada kerja sama antara toko kertas dan juga percetakan maka seluruhnya akan langsung dikerjakan oleh percetakan.

Selain itu, juga ada mekanika digital yang perlu diperhatikan terhadap desain logo. Maka logo didesain dengan grid system yang akan mempermudah proses reproduksi logo selanjutnya. Pengaplikasian logo dilakukan pada setiap 
media desain kemasan yaitu kemasan gula aren padat $250 \mathrm{gr}$, kemasan gula aren padat $400 \mathrm{gr}$, kantongan untuk pembelian satuan, kemasan paket hemat yang terdiri dari gula aren padat $250 \mathrm{gr}$, kemasan paket eksklusif yang terdiri dari gula aren padat $400 \mathrm{gr}$. Kemasan untuk paket hemat didesain seperti kantongan agar mudah dibawa, untuk kemasan paket eksklusif menggunakan box yang mempunyai motif kayu untuk membuat kotak tersebut terkesan natural, alami, dan eksklusif. Begitu juga dengan kardus distribusi akan diaplikasikan logo.

Setelah pemberian materi pelatihan pengembangan produksi gula briket aren dengan pengemasan menarik yang memiliki nilai jual tinggi bagi para pengusaha gula briket aren di Desa Bukit Tinggi, selanjutnya untuk menghasilkan prodak kemasan menarik setelah pelatihan ini, terlebih dahulu dilakukan perumusan konsep kemasan menarik berdasarkan materi pelatihan yang dielaborasi dengan potensi gula briket aren desa Bukit Tinggi, dilakukan melalui focus group discussion, dan workshop, sehingga pelatihan ini secara kongkrit tidak saja menghasilkan konsep kemasan menarik dengan nilai jual tinggi melainkan juga menghasilkan prodak kemasan menarik berdasarkan konsep yang telah dibangun tersebut. Dan pada akhirnya melalui workshop semua peserta pelatihan menghasilkan kemasan menarik yang memiliki nilai jual tinggi, dapat dilihat pada gambar berikut:

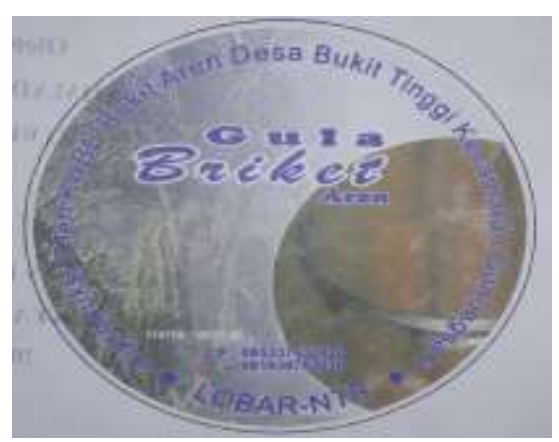

Gambar 1: Desain Kemasan Menarik Gula Briket Aren Hasil Pelatihan Para Pengusaha Gula Aren melalui Desa Binaan di Desa Bukit Tinggi

\section{PENUTUP}

Untuk dapat mengembangkan produksi Gula Briket Aren di Desa Bukit Tinggi maka perlu ditopang dengan mindset pegusaha gula briket aren itu sendiri yaitu mereka harus punya semangat optimisme yang tinggi disertai usaha-usaha kreatif 
untuk sukses dalam mengembangkan produksi Gula Briket Aren di Desa Bukit Tinggi.

Usaha kreatif tersebut sangat dituntut dalam mengembangkan produksi gula briket aren dengan kemasan menarik yang memiliki nilai jual tinggi sebagai trend konsumen yang cenderung mudah tertarik dengan kemasan menarik sekarang ini, dengan mengedepankan konsep fungsi kemasan bukan hanya menjadi pelindung untuk sebuah produk, melainkan sebuah kemasan juga harus mampu memberi citra bagi produk, dengan demikian produk akan dengan mudah dapet diingat melalui kemasannya. Rasa dari produk yang enak tidaklah cukup untuk menarik pembeli, sehingga penambahan unsur visual agar produk menjadi lebih menarik bagi pembeli sangatlah penting.

Dengan unsur visual, maka dipakainya brand name Gula Briket Aren KUBE Bukit Aren desa Bukit Tinggi menjadi logo sebagai identitasnya ingin mengkokohkan pencitraan terhadap produk gula briket aren ini. Brand Identity menjadi suatu elemen yang sangat penting dimana brand identity harus menampilkan citra dan identitas sebuah brand. Brand identity wajib dimiliki oleh sebuah brand untuk menyampaikan image sesuai dengan karakter serta visi dan misi para pengusaha gula briket aren. Brand identity dapat menguatkan brand awareness masyarakat terhadap sebuah merek. Ciri khas sebuah merek pun dapat diingat dengan mudah melalui tampilan visual. Brand identity yang tepat akan memudahkan target audience untuk mengingat keberadaan brand tersebut, sehingga mampu meningkatkan angka penjualan produk yang ditawarkan. Hal ini juga akan memicu peluang perusahaan untuk mengembangkan pemasaran produknya.

\section{DAFTAR PUSTAKA}

Adams, Sean. Master of Design: Logos and Identity. Massachusetts : Rockport Publishers, Inc., 2008.

Cenadi, Christine Suharto. Peranan Desain Kemasan Dalam Dunia Pemasaran, Nirmana Vol. 2, No. 1, Januari 2000.

"Gula Aren". Bank Indonesia. 2009. 10 Mei 2009. <Gula Aren, 
http://arenindonesia.wordpress.com/panduan-tentangaren/bank-indonesia/>

Kamus Besar Bahasa Indonesia Pusat Bahasa Edisi Ketiga. Jakarta: PN Balai Pustaka, 2001.

Kartajaya, Hermawan. Marketing Plus 2000 Siasat Memenangkan Persaingan Global. Jakarta: Gramedia

Pustaka Utama, "Kemasan". Arti Kata. 2013. < Arti Kata, http:// artikata.com/arti367857-kemasan.html, dikses 7 Februari 2013

Klimchuk, Marianne R., dan Sandra Krasovec. Desain Kemasan Perancangan Merek Produk yang Berhasil Mulai Dari Konsep sampai Penjualan. Jakarta : Erlangga, 2007.

Kotler, Philip. Manajemen Pemasaran : Analisis, Perencanaan, Implementasi, dan Kontrol. Trans. Budiman Mahendra. Jakarta : PT. Prenhallindo, 1998.

"Kenapa Gula Aren Lebih Sehat Dari Gula Pasir?". Detik Health. 2011. 11 Januari 2011. <Kenapa Gula Aren Lebih Sehat dari Gula Pasir?, http://health.detik.com/read/kenapa-gula-aren-lebihsehat-dari-gula-pasir>

"Kemasan". Arti Kata. 2013. 7 Februari 2013. <Arti Kata, http:// artikata.com/arti367857-kemasan.html>Rustan, Surianto. Mendesain Logo. Jakarta: PT. Gramedia, 2009.

Sanyoto, Sajiman Ebdi. Nirmana: Dasar-dasar Seni dan Desain.Yogyakarta: Jalasutra, 2009. 